\title{
Urbanalisation: Common Landscapes, Global Places
}

\author{
Francesc M. Muñoz*
}

Universitat Autònoma de Barcelona, Barcelona, Spain

\begin{abstract}
Discourses on urban globalisation have been considering the homogenisation of the built form as evidence of the impacts of internationalisation of economy on the city space. This is a statement that follows other similar approaches: the existence of a global architecture, the global domain of mass-media or the imposition of homogeneous lifestyles all around the planet. However, despite the fact of the repetition of some key spaces which are similarly replicated in cities around the world, it is also clear that differences between cities still remain. This paper suggests the concept of urbanalisation as based not on the homogenisation of cities and places but in the management of differences among them. This is to say, urban landscapes are not identical but they can appear as similar as the management of local special features allows. Thus, the explanation of the relationship between globalisation and the built urban environment focuses on the development of standardisation criteria that make differences between cities less evident. Architecture and urban design are used in this way as a real transformer that locates differences and peculiarities into a much simpler and understandable built form without any need to erase them. From this perspective, urbanalisation reveals a process of simplification of the city in which urban diversity and complexity are reduced to fit into a common visual order.
\end{abstract}

Keywords: Urbanalisation, urban planning, urban geography, landscape, global economy.

\section{URBANALISATION: LANDSCAPES OF URBAN CHANGE}

This paper develops the concept of urbanalisation [1-4] to explain the recent changes in the configuration of the urban form in western cities. The process of standardisation and replication of similar urban spaces in different cities is presented in a critical way suggesting that this is not a dynamic dealing with homogenisation but with just the opposite: the management of the differences and peculiarities characterising different places. According to this approach, the similar built environment characterising renovation areas in cities is not simply the result of the same specialised urban functions being developed in urban space. Nor is this common urban form merely the result of the participation of the same global architectural offices in those urban projects. These explanations can be useful as descriptions of some case studies but they fail as general explanations of the production of a highly standardised urban landscape in very different cities.

This paper suggests that this production of common urban landscapes is based on the use of strategies like imitation, selection or the use and manipulation of urban history and historical urban form. More specifically, the use of both a commodified cosmopolitanism, characterising the new urban spaces, and a marketed romanticism, which is used in the design of these landscapes, explain the management of local differences to produce a global visual order of city space after urban renovation. This is a process in which urban design and architecture are the main tools for the production of the common landscapes of urbanalisation: the banalscapes.

*Address correspondence to this author at the Universitat Autònoma de Barcelona, Barcelona, Spain; Tel: +34 625445476;

E-mail: franc.munoz@uab.cat
The paper examines this analysis in relation to the recent evolution of urban policies and city transformation. Key points and dynamics are summarised in relation with the idea of "festivalisation" [5] of urban policies and with the process of adaptation of urban space to new functions directly linked with leisure, consumption, entertainment and global tourism. The success and development of these festivalised urban policies must be understood considering the priority given to the participation of the city in global markets of production and consumption, which seems to be the main scope of urban planning in a wide range of cities at the present moment. In this sense, most of the urban renovation projects recently developed in western cities show the production of an exchanged urban space previously selected and properly renewed. Waterfronts, old industrial areas and historical centres are good examples of this similar process taking place not only in central cities like Berlin or London but also in others which have developed important urban transformation projects, such as Bilbao or Barcelona.

The urbanalisation process and the production of banalscapes are defined in terms of three main requirements:

- $\quad$ The fabrication of an urban image as the main element required to start and feed the process of urban production.

- The hypervisibility of urban security conditions present on the urban arena and directly related to the appearance of a "lock living" urban lifestyle.

- $\quad$ The use of specific urban morphological elements, like public spaces, in terms of leisure surfaces.

These three new conditions for the production of urban space reinforce three main results of the urbanalisation process:

- $\quad$ Economic and functional specialisation of urban space.

- Morphological segregation of the urban form. 
Thematisation of the urban landscape.

Finally, the process of urbanalisation does not only refer to the production of built environment but involves parallel dynamics of construction of urban culture directly associated with the visual order defined by the banalscapes. In this sense, the selection of some elements of urban history and historical urban form in which the thematisation of urban landscape is based, shows how not all the urban stories have their place in this process. Only those which can be easily read and understood, reduced and simplified into the images previously shown in tour-operators' brochures are finally present and contributing to the urban image. This is an urban past and a present reality which are performed in a legible and friendly way $[6,7]$. In this sense, architecture and urbanism are used in the urbanalisation processes to produce a kind of globalised local urban landscape. This is a banalscape which is created according to some characteristics of the local physical and social space but, at the same time, respecting the requirements of the global franchising economy.

This essay develops these statements to analyse the process of urbanalisation and the appearance of the banalscapes. Some study cases refered to Spanish cities are explained and some theories on key concepts such as spectacle, suggested by Guy Debord [8], and banality, developed by the Spanish philosopher José Luís Pardo [9], are used to provide this critical analysis.

\section{THE FESTIVALISATION OF URBAN POLICIES AND THE EXCHANGED CITY MODEL}

Marco Venturi [4] referred to the concept of festivalisation: the appearance and development of urban policies specifically conceived considering the necessity of a "big event" as the engine of the urban transformation. These festivalised urban policies have considered the participation of the city in the global markets of production and consumption as their main goal. Taking into account these priorities, this kind of urban policy needs the implementation of urban marketing programs.

These programs deal, firstly, with the creation of an urban image, capable enough of attracting hypermobile global capital and, lastly, with the construction of an urban reality able to keep these investments [10].

These image programs represent a real inversion in the order of elements participating in the production of urban space, in the sense that the image must be created before the urban form is produced. Since the XIXth century, the celebration of big urban events, such as International Fairs, World Exhibitions and Olympic Games has required the urban image as a very important element in the process of commercialisation and marketing of new spaces in the city. However, this marketing process used to be developed after the city had been constructed or renewed. Nowadays, it seems evident that the image has become a necessary condition for the urbanisation process itself. This explains why the urban image needs to be promoted and marketed before a brick is laid.

If present day cities need urban marketing this is because the image of the city is a basic factor in attracting investments. It is only after this that the new urban developments are finally built. This is to say, urban policies mainly focus on the creation and promotion of urban images more than on the production of the cityspace itself. Therefore, the production of landscape which is behind these kinds of processes has been developed in a context characterised by a serious crisis in urban policies in western cities $[11,12]$. In fact, over the last twenty years, urban policies have experimented with a process of simplification and reduction of their objectives and goals as can be observed in so many different experiences of urban renovations. These very different renewal experiences show that urban policies have been focusing more on the development of specific great scale urban projects more than on global programs to improve the quality of the city as a whole.

Furthermore, we can suggest a transition from a kind of urban intervention conceived as an instrument for the regeneration of the city, to the kind of projects which draw as the main priority the sale of the city as another product in an international market, in the context of the global economy. In this process of 'selling' cities and places [13] several factors have simultaneously been implicated but the urban policies have contributed in a very important way to the final scenario. This is because they have assumed as their main role the economic and physical transformation of some specific fragments of the city, previously selected from the urban fabric. This has happened with specific territories of transformation like the historical areas and waterfronts. Thus, this sale of the city reveals the transition from the idea of change, in the sense of regeneration of the urban space, to the idea of transforming the city into something to exchange for investment. This transition from the changing city to the exchanged urban form has characterised the evolution of western urban policies over the last three decades.

\section{FROM PRODUCTION TO CONSUMPTION: ECONOMIC SPECIALISATION AND THEMATISATION OF HISTORICAL CENTRES}

This general evolution is the result of a structural trend in recent urban history of contemporary cities: the progressive conversion of urban historical centres in places oriented towards consumption, entertainment and other activities linked with global tourism.

The risks of reduction of urban functions in these central areas deal with a process of specialisation which has not always been perceived in a critical way from the point of view of urban policies. Indeed, in many cases these urban policies have been embraced; this has therefore been the beginning of a real process of thematisation of the cityscape. I define this concept as the exportation of uses of the space and time characteristic of leisure and consumption containers, such as shopping malls or theme parks, to the urban space.

This is to say, the traditional places of the city -the architectural setting, the topological elements like streets and squares, which have historically characterised the compact city as vibrant public urban spaces- are transformed following a very similar pattern of intervention which deals with a highly standardised type of urban experience. A very interesting paradox can be suggested here: During the past half century, leisure and consumption containers have been 
intensively recreating and imitating urban atmospheres, specific places and formal features of cityscapes: the street, the square, the boulevard, the park, etc. Nowadays, it seems that cities, to be successful as places to be visited and consumed, need to imitate that urban form, based on imitations of the city spaces themselves, found in shopping malls, festival markets or theme-parks. This is a process that contributes and reinforces the standardisation of urban landscapes.

Despite this diagnosis, former urban regeneration programmes used to focus on the diversification of economic activities and the maintenance of residential functions. They used to conceive inner cities as complex urban environments. However, the majority of urban renovation experiences have finally provoked exactly the opposite results: the economic and functional specialisation, the morphological segregation of the urban form and the thematisation of the urban landscape. These three elements characterise what I call urbanalisation. Even when the residential function has been maintained in the experiences of urban renewal, the historical areas have acquired a new function: they have been renewed as a city not to be daily inhabited but to be intensively visited.

To summarize, the contemporary city generates a double flow in relation to urban transformation: Firstly, the production of specialised islands, dedicated to production or consumption. Secondly, the recognisable urban forms of the compact city, those areas where topological elements like streets or squares contribute to the urban fabric, are also converted into specialised containers. Despite the morphology of the city being maintained, the urban functions have been simplified in a thematic way. The more recent example illustrating this process of urban thematisation can be observed in urban renovation affecting Jewish ghettos in Eastern Europe. These old neighbourhoods are renovated following a very similar pattern in different cities and offering a final scene where the historical urban form is merely the visual support for a highly specialised use of the space orientated towards leisure, entertainment and consumption [14]. The results of these renovation experiences reveal a city which has been simplified in terms of its attributes and contents. Similar results can be observed in so many experiences of urban renovation in historical centres and waterfronts in Europe ${ }^{1}$.

This banalisation of the urban form can now be analysed in the light of some definitions of the culture of banality offered by the Spanish philosopher José Luís Pardo [9].

\section{A COMMON ITINERARY TOWARDS URBANALISATION}

José Luís Pardo [9] refers to banality as a condition of our contemporary society and culture. Through his explanations, Pardo describes what he calls the semantic

\footnotetext{
${ }^{1}$ Paradoxically, historical areas and waterfronts have also been the spaces more culturally identified with the urban attributes characterising the industrial city. The urban iconography created by the cinema, for example, have always shown key contents of urban life clearly present in these two specific landscapes: density, intensity, relationships, hazard, chance, or conflict. A film with a very meaningfull title, On the waterfront, by Elia Kazan (1954), is a very good example. Since the very beginning to the end, the association between the city and the port is clearly present and the previously mentioned city attributes characterise the action.
}

cartography of mass culture defined by the global economy. Pardo suggests that this semantic cartography is based upon two different systems of co-ordinates: the system of flavour and the system of brightness. The first system is characterised by two elements: energy and fun. The second is characterised by other two: softness and cleanliness.

According to Pardo, banality is the result and banalisation is the process of becoming banal. Any space on the map of banality, and any moment in the process of banalisation, can be defined considering a combination of these two systems, more specifically, as a particular combination of the four elements constituting them: energy, fun, softness and cleanliness. In this way, a banal object would be characterised by containing specific doses of these four elements [15].

Pardo suggests four prototypical examples of objects which are framed by the two systems of co-ordinates. This arises because they are the result of the possible combinations of the four components:

- $\quad$ Sugar-free chewing gum: it is something fun because it is sweet, but, at the same time, it is something clean, because it does not cause dental problems. This specific combination of fun and cleanliness results in a flavourful and a shiny final content. So, the two systems of co-ordinates, flavour and brightness, are clearly represented through two of their constitutive elements.

- $\quad$ Light cigarettes: which represent everything which is fun, because they contain nicotine, but soft, because they contain half the amount? In this case, the banal object is the result of the combination of fun, from the system of flavour, and softness, from the system of brightness.

- Detergent with colour protectors: This is energygiving, against stains, but, at the same time, soft, on the fabric.

- $\quad$ Meat with low fat content: which is a combination of energy, because it contains vitamins and proteins, but, at the same time, of cleanliness, because it does not increase our cholesterol level.

As we can see, the right doses of the four components assure the location of every banal object in the general process of banalisation, where they find their place and their function. Pardo defines this process in a very specific way:

... the way in which behaving, thinking, saying and feeling are framed in the co-ordinates of the system of flavour and the system of brightness. Both systems try to incorporate everything which is not banal, everything which is worth being felt or said [15].

Urbanalisation and the production of banalscapes can be also explained in a similar way, considering Pardo's two systems of co-ordinates. Using his words, the urbanalisation process could be defined as:

\footnotetext{
...The way in which the ways of thinking, projecting, behaving and, finally, inhabiting the city are framed in the co-ordinates of the system of flavour and the system of brightness. Both
} 
systems try to incorporate every possible form of non banal city...

Furthermore, urban renovation is based on the production of flavourful and shiny urban spaces, brand-new places which must necessarily be fun but clean, energy-giving but soft. Landscapes constituted as perfect combinations of flavour and brightness: the banalscapes.

But how are these banalscapes introduced into the coordinates of banality? Which spatial attributes of the city are considered in the process of urbanalisation?

\section{URBANALISATION: THREE NEW URBAN REQUIREMENTS}

Taking the metaphors suggested by Jose Luis Pardo [15] further, we can ask ourselves about the existence of specific dynamics and strategies operating on the production and multiplication of banalscapes.

In other words, are there any conditions specifically required for the development and reinforcement of the urbanalisation process?

Three different requirements can be pointed out in this explanation:

- The fabrication of an urban image as the main element required to start and feed the process of urban production.

- The hypervisibility of urban security conditions existing in the urban arena and directly related to the appearance of a lock living urban lifestyle.

- $\quad$ The use of urban public spaces, in terms of leisure surfaces.

Some comments can be suggested on each of the above.

\section{THE URBAN IMAGE AS THE PRIME ELEMENT ON THE PROCESS OF URBAN PRODUCTION}

As previously mentioned, image has changed its place in the process of urban production. It is no longer something outside this process or only required for assembling the collective narration of urban change. Instead, the fabrication of the urban image is a basic condition which guarantees the competitiveness of a city on the capital global market. A wide range of cities are currently competing to attract the economic uses of space that represent higher investments and the urban image has become a landmark in this process of urban competition. The physical transformation of the cityscape lays then on the necessity of urban design which is understood as the production of an image for the city: easily recognizable, exportable and even more easily consumable by both visitors and inhabitants. By this process, the urban image transforms itself into nothing more than a label, a brand. Some authors such as John Hannigan [15] (1999) have elaborated on this process of urban brandification. When the design of cityscape and the production of brandnew urban spaces follow the aesthetic rules defined by that specific urban image, the city is no longer a physical space to be inhabited but instead a cultural frame to be experienced. In this sense, urban spaces merely become containers for the urban events that reproduce the urban brand. The case of Barcelona and the production of new urban spaces respecting the aesthetic idea of the "Mediterranean city" is a very good example of this process which refers to the conversion of the city itself into a brand.

This is actually a very interesting paradox which goes hand in hand with the transition from urban marketing to urban branding: cities have been using urban design to remark local elements, underlining the specific and vernacular, pretending to appear as different in order to result more attractive to the global economy. However, what the brandification process associated with urbanalisation shows is, in fact, just the opposite; cities appear as indifferent places where a common urban image and experience is overexposed.

\section{THE HYPERVISIBILITY OF URBAN SECURITY CONDITIONS: ARCHITECTURES OF SILENCE}

The consumption of security conditions and devices makes up part of the urban lifestyle. In her very well known book Loft Living [16], Sharon Zukin discussed prime gentrification processes in New York and analysed how urban renewal was going hand in hand with important social and cultural changes. Zukin suggested that middle classes were inhabiting urban space through new lifestyles and consumption patterns that explained, not only, the transformation of old industrial warehouses into lofts, but cultural phenomena like the success of nouvelle cuisine offered at that time in the brand-new restaurants.

The increasing development of security policies highly associated with design and use of urban space can be explained in a very similar way. It can be explained as a process directly linked with changes in urban lifestyle. This is a new lifestyle based on the demand for protection, defence and surveillance as a new way of social identification. Security policies make clear the separation between those inhabitants protected defended and under surveillance and those others who are not part of the urban community.

From this perspective, the purpose of surveillance cameras is to be more an element of social cohesion among those who feel protected, than an instrument orientated towards a panoptic urban design. In other words, the presence of surveillance cameras can be explained in terms of a system of landmarks which signal the urban spaces which are part of the normalised city in terms of urban economic value. This explanation would explain the hypervisibility of security conditions much more than the anxiety for protection or the feeling of fear. If this is true, a new lifestyle can be appearing based on the desire for the use of safe urban spaces. In this sense, we can suggest the idea of lock living urban environments [2]. The design of urban environments incorporating these security conditions is a way to guarantee the economic value of both private and public urban spaces. This approach would explain the very high degree of standardisation characterising urban policies based on security. The so-called "architecture of fear" would not really be based on fear but on consumption and the maintenance of urban value.

Whatever the cause, it is true that new urban developments must increasingly respect specific security conditions and criteria at the present moment. Those requirements directly affect urban design not only regarding the architecture and formal languages used in specific 
buildings but when facing the conception of urban areas as a whole. It is in this urban planning and design of streets or neighbourhoods where a main risk can be detected: the more oriented towards guaranteeing security conditions urban design is, the simpler the urban projects shaping the physical space in the city. In this context, the complexity characterising the city, which has been historically seen from the planning side as evidence of its efficiency in terms of social machine -the well-known machine a habiter in Le Corbusier's words-, is progressively understood as a problem. This is to say, the diversity of urban atmospheres and activities and the multiplicity of simultaneous uses of urban space, are beginning to be evaluated as an obstacle for obtaining the optimum security conditions. In other words, the more complex urban space is, the more difficult is to control in the case of an emergency or terrorist attack.

Thus, the priority given to security aspects on urban planning demands the production of an oversimplified and highly predictable urban space. This result poses a real paradox: the same security protocols which could theoretically maintain the qualities of urban spaces, guaranteeing the normal development of urban social interaction and the diversity of urban life, are in fact producing urban spaces which are characterised by just the opposite. Since urban security programs are equally cloned and implemented in one city after another, the urban space appearing as a result of the urbanisation process is as highly standardised as those security policies. Through this orientation towards guaranteeing maximum security conditions, urbanism becomes clearly framed into the coordinates of urbanalisation.

The main consequence for architecture here is the progressive incapability to express collective meaning and culture. In some way, lock living urbanism demands architecture in permanent silence.

\section{THE USE OF URBAN PUBLIC SPACES IN TERMS OF LEISURE SURFACES}

Public spaces are a very significant part of the cityscape and have been dealing with important changes related to both their morphology and their function. This transformation basically refers to a process of specialisation, in a context characterised by the orientation of the city space towards leisure, entertainment and consumption.

Public spaces used to be defined by multiple and simultaneous uses and users. It was in this way that public spaces were clearly different in comparison with private spaces in the city. This is to say, public spaces were specifically hosting both collective uses of the city space and symbolic representation of community culture and identity. According to this, they were important spaces characterising the city as a built environment where social and political life could take place.

Considering this previous role, specialisation of public spaces towards uses directly linked with leisure, entertainment and consumption clearly refers to what Sharon Zukin named years ago as a process of "domestication by cappuccino" [16]. This process of "domestication" has to do with the acquiring of a new double role: one role being physical enclaves signalling the borders of the gentrification process and the other role working as resting areas where one can stay when visiting the city, in the same way we can find them on the margins of highways.

We can confirm these trends when observing that the diversity characterising the use of public spaces is in fact a very essential element contributing to the general process of commodification of urban landscape. This process goes hand in hand with the orientation of more and more urban spaces towards global tourism: local squares, specific streets or even neighbourhoods show how public spaces are transformed into thematic spaces where key elements of local culture, offered in terms of diversity and cosmopolitanism, can be found. This merchandising of urban cultural souvenirs finds in public spaces the best place to be developed and shows the reduction of complexity in public spaces being substituted by a new function: being a surface where urban images dealing with both gentrification and thematisation are exposed. It is in this sense that current evolution of urban public spaces must be understood as framed by the general process of urbanalisation.

\section{THE PRODUCTION CHAIN OF COMMON LANDSCAPES: THE BANALSCAPES}

The spaces of urbanalisation, like waterfronts, historical centres and specific areas of urban renovation, show how urban design and architecture are used for the standardised production of common landscapes. Some strategies can be identified in this sense, such us the manipulation of history at different levels. As mentioned previously, the selection of some elements from local urban history and from local historical urban form show how not all the stories characterising this past have a place in this process. Only those elements which can be easily read and understood are considered.

The urban past is recreated presenting a legible and friendly $^{2}$ urban result. In this sense, architecture and urbanism are used in the process of urbanalisation to produce an urban landscape which is 'locally globalised'. This means that it has been designed and created recovering some of the characteristics of the physical and social local space but simultaneously respecting the requirements of the franchising global economy.

This is a process which can be understood and explained using the second definition of spectacle given by Guy Debord in The Society of Spectacle ${ }^{3}$ [8]: "spectacle is capital accumulated to that level in which it has become image". In this case, we could say "landscape". The consequences of these dynamics show the progressive specialisation of some urban territories which are orientated towards the production of a very specific kind of landscape. Those specific urban morphologies are conceived and adapted for the visual and thematic consumption of visitors. In Ignasi de Solà-Morales words [17]:

\footnotetext{
2 In Landscapes of Power, Sharon Zukin presents a comprehensive explanation of these processes. She uses both terms, 'legible' and 'friendly', to refer to a production of landscape which reformulates the relationships between market and place.

${ }^{3}$ Debord gave two different definitions of the idea of spectacle:

- Spectacle as a relationship between people mediated by images.

- Spectacle as capital which has been accumulated to that level in which it has become image.
} 
... We are facing the experience of a new massmedia culture, in which distances are shorter and shorter till they become instantaneous. A mass-media culture characterised by the fact that the reproduction of images, with all kind of mechanisms, makes them non-linked with one specific place but flowing, in an erratic way, through the length and width of the planet...

It is therefore possible to identify some criteria which are behind the production of the banalscapes, inspiring this production of urban image. We can suggest a real system of production of common landscapes. A system characterised by the use of some strategies that will be discussed here.

\section{THE USE AND MANIPULATION OF HISTORY: COMMODIFIED COSMOPOLITANISM AND MARKETED ROMANTICISM}

While formal specificities of local urban space can be disregarded and even be erased from the surface of the renewed city, local urban history is paradoxically used and manipulated in the process of production of common landscapes. This process is based on two main directions:

Firstly, the local ancient architecture, the vernacular formal languages characterising urban form and peculiarities of the old built environment, are used in the production of banalscapes. The simulation of pre-industrial urban atmospheres and the recreation of the softer images of the industrial city deals, in this way, with a recognisable strategy, which can be named as commodified cosmopolitanism.

Secondly, the local stereotypes involving the community of inhabitants in previous historical moments are also considered. They refer to a supposed and, on many occasions, fictional old community, representing an idealised urban past which is presented and consumed in terms of nostalgia. These cultural ingredients are used in the assembly-line of images which makes up the atmosphere of thematisation characterising the banalscapes. In this way, a kind of marketed romanticism, which constitutes a second strategy, can be distinguished. This production of landscape, directly associated with the consumption of nostalgia, is one of the most important elements characterising the tourist gaze $[18,19]^{4}$.

This double manipulation of the history of the place through the two strategies, the commodified cosmopolitanism and the marketed romanticism, reveals the use of specific

\footnotetext{
${ }^{4}$ In his writings on the so-called post-Fordist tourism, John Urry points out different forms of the tourist gaze: romantic, collective, spectatorial, environmental and anthropological. The romantic one is characterised by being 'solitary', involving vision and related to the consumption of nostalgia. Urry also discusses some patterns in the post-fordist tourist skills and perceptions which make up an 'aesthetic cosmopolitanism'. This is defined by some elements such as a curiosity about all places, peoples and cultures, a willingness/ability to appreciate elements of the language/culture of the place that one is visiting, or a willingness to take risks by virtue of moving outside the tourist environmental bubble. The two strategies of production of common landscapes that I am discussing here, the commodified cosmopolitanism and the marketed romanticism, are nothing more than the appropiate response to these patterns characterising postfordist tourism, from the architecture and urban design side. Both strategies are, therefore, the physical and aesthetical response to frame the tourist gaze in the co-ordinates of banality.
}

methodologies for the production of banalscapes such as imitation and selection.

Therefore, regarding commodified cosmopolitanism, imitation refers to the fact that, in the renovation areas, the design of both the built environment and the public spaces is conceived as a simple imitation of the urban spaces of the past. Selection refers to the fact that not all architecture is able to be maintained and represented in the process of urban renewal. Some examples referring to different renovation areas developed during the 1990's decade in European cities can illustrate these points. The well-known experiences in the London Docklands, the Olympic Village area in Barcelona, and the historical renovation in Palermo are good key studies which help to explain the use of imitation and selection regarding the commodified cosmopolitanism.

In the cases of London and Barcelona, the imitations of the pre-existing city and its image of a complex environment constitute the most important aspect to be discussed. In this sense, the simulation of urban diversity, which is normally contained in the urban landscape historically, tries to present the renovated area as an organic and natural extension of the existing city. This controlled architectural diversity reveals the ambition for imitating some specific historical architectures of the ancient city and some features of the historical urban form and landscape previously selected.

In the case of Canary Wharf area, the architectural teams worked hard on a project of morphological identification of the historical city. They developed a photographic analysis, searching and selecting which kind of public spaces and which specific formal characteristics of the historical buildings should be considered to be imitated in the renovation area [20].

In the case of the Olympic Village area in Barcelona, the architectural teams re-elaborated certain elements of the vernacular historical architecture. The main goal was to give the impression of a consolidated part of the city, well rooted and linked with the pre-existing historical urban areas. The idea of in vitro architecture [21], which was marketed as one of the main guidelines of the global architectural project, clearly show this simulation of the history of the place based on imitation and selection.

Finally, the case of the historical renovation in Palermo shows how far this first strategy of commodification of the historical urban form can go. In this case, selection refers to the fact that, in the different projects implemented for the recuperation of the historical centre, the Islamic past was not considered. Despite the fact that this Islamic heritage had a very important presence through specific morphological elements in many historical buildings, it was disregarded when selecting the constructions to be renewed [22].

After considering imitation and selection in relation with the first strategy, the commodified cosmopolitanism, they can now be discussed in relation with the second one, the marketed romanticism.

As previously mentioned, this second strategy deals with the manipulation of local stereotypes not only referred to the old inhabitants of the city, but also to the events of the past linked with them. A romantic gaze is thus projected on their urban experiences and lives, which are reinterpreted and 
presented in an idealised way. The renovation experiences in Bilbao riverside and Barcelona waterfront during the 1990's show interesting examples of this strategy and the methodologies at work.

In the case of the redevelopment of Barcelona waterfront, references to this idealised ancient community of inhabitants are presented through a romantic vision of the idea of mediterranity. The romantic images of the old port are used not only in the design but also using photographic stages showing selected scenes from the past. Black and white fragments of past urban life in the port such as the community of fishermen or the harbour workers. These are images which inspire commodified consumption of the local stereotypes. They can be easily appropriated as small tastes of the past, as little gift-wrapped souvenirs to take away.

This kind of marketed romanticism is also present in the former redevelopment in the London Docklands. In particular, the case of Saint Catherine Docks, where the thematisation of public spaces, streets, promenades and the same buildings makes continuous references to the commercial trade of tobacco.

In the case of post-Guggenheim Bilbao, the references to this idealised and fictional community of inhabitants use imitation and selection to present the renovation area as it was before the process of industrial growth. A symbolic and organic relationship with the old riverside is shown referring to the recuperation of an (idealised) urban past. A past which was stolen by fordism and now is given back to the city. In this sense, the new urban projects in the riverside are presented as a recuperation of the authenticity of the city which had remained forgotten and obliterated because of the wild industrial growth.

These very different key study areas illustrate how some specific strategies and methodologies produce the common landscape of urban renovation. The two strategies, the commodified cosmopolitanism and the marketed romanticism, and the two methodologies, imitation and selection, are the basis of the system for the production of the flavourful and shiny urban spaces where banalscapes can be found. This means, a production of city image perfectly framed in the co-ordinates of flavour and brightness, where only selected elements of the local history and the local urban form are present. Thus, it is not the whole urban history which is represented but one which the visitor or the tourist has in mind and hopes to find. The historical urban form which is both maintained and represented in the renovation areas is the one which allows a quick and simplified understanding, the one which has been previously typified by the mass-media assembly-line of images and distributed by the global tour-operator brochures. In Stephen Barber's words [23]:

$$
\begin{aligned}
& \text {...The selection of material for the city's } \\
& \text { museums of identity necessarily involves an } \\
& \text { excision of particular elements from its } \\
& \text { history.... The amputation and transplantation } \\
& \text { of the material and imagery of history into the } \\
& \text { transmissible form of vital memory is the most } \\
& \text { sensitive process in the gathering of identity for } \\
& \text { the city. The version of the city which is created } \\
& \text { supplants previous identities, the traces of }
\end{aligned}
$$

which suffer a sudden, random diminution of their visual presence, so that determined elements of the city's history become peripheral, located far beyond the habitual visual trajectories of the city's inhabitants...

\section{URBANALISATION IN SPANISH CITIES}

Considering what has been previously mentioned, we can conclude that the main consequence of urbanalisation processes on local environments is the disconnection between place and landscape. This is to say, landscape has been traditionally understood as the morphological translation of the physical features and the social and cultural relationships that define the place and shape the so-called as genius loci. However, cities are currently facing the appearance of landscapes which are clearly independent from the place in the sense that they can be replicated in any other city. In this context, landscape no longer translates the features of the place as could be expected and neither does it contain cultural or symbolic attributes related to social identification and cohesion.

This process of disconnection between place and landscape has specifically characterised the recent evolution of Spanish cities and can be easily observed in three different scenarios:

- The brandification of historical neighbourhoods. In these old urban areas, gentrification processes and the orientation of urban space towards leisure and consumption has gone hand in hand with the visual occupation of strategic plazas and streets by the brands linked with the global franchising economy.

- The renovation areas located in urban waterfronts and riverside areas. In those spaces, standardised architectural and urban design programs have been implemented revealing a highly restricted menu of options: the aquarium, the shopping area, the leisure sector, the IMAX cinema, the local museum or cultural centre and the high-rise residential areas configuring a brand-new urban seafront.

- The new urban sprawl areas on the outskirts of traditional compact cities. These new peripheries reveal the appearance of a highly standardised residential landscape. This is a sprawlscape [24] defined by being easily reproducible and independent from the historical background, the physical features and local culture that normally characterise places.

The three scenarios reveal, in different ways, the main consequence of urbanalisation: the loss of urban diversity and complexity which results from specialisation of city spaces and thematisation of cityscapes.

Firstly, brandification processes in Spanish cities can be detected both in the historical centre and high-streets located in the modern extensions of the old city traditionally orientated towards leisure and shopping. The regeneration of the old urban matrix and the implementation of some urban policies, such as the transformation of strategic streets into pedestrian walkways, far from maintaining the existing diversified economic uses and population, have lead to the acceleration of gentrification dynamics and specialisation. In this context, those uses of the space which can compete 
better for the urban land, such as new lofts or branded shops are clearly present characterising urban landscape. A significant part of these franchised shops corresponds to telecommunication brands. This is something very specific of Spanish cities.

The increasing number of cell phone users has encouraged the three main brands controlling the Spanish market -Vodafone, Orange and Telefonica- to literally colonise main locations in the city centre to offer telecommunication services to their costumers. The fact that the three firms work with a clearly recognisable corporate image based on three different colours -red for Vodafone, orange and black for Orange and blue for Telefonica- has had as a consequence an intensive and accelerated process of specialisation and visual equalisation of ground floors in many streets and plazas. Far from keeping the old city alive, maintaining vernacular architecture and traditional uses of space, this process has contributed to standardise the urban landscape that can be found on some relevant areas of the Spanish cities.

This is a transversal process which evolves crossing the hierarchical structure of the Spanish urban network. So, this visual occupation of meaningful urban spaces by telecommunication brands can be found in main capitals, such as Madrid or Barcelona, important cities, like Valencia, Bilbao, Seville or Saragossa, but also in towns and main villages which are economic centres in traditionally rural counties. The evolution of these different urban centres reveal a process of urban sampling and replication that underlines the repetition of uses and morphological features found in British main cities and high-streets of new towns, as some surveys have recently suggested ${ }^{5}$.

Secondly, urban renewal in waterfronts and riverside areas has characterised urban renovation in some Spanish cities. Barcelona, Bilbao and Valencia are three different key study cases. Barcelona and Bilbao offer clear examples of the strategies and methodologies supporting urbanalisation as mentioned previously. In the case of Barcelona, the projects that opened the city to the seafront for the Olympic Games in 1992 have been continued in the operation to complete the waterfront renovation developed hand in hand with the celebration of the Forum of Cultures in 2004. In Bilbao, the riverside area has undergone a very intensive process of urban renewal as a consequence of the so-called Guggenheim effect.

In the case of Valencia, the renovation of the waterfront area has involved the extension of the containers terminal at the port but mainly with the development of a whole new built urban environment along the seafront and surrounding areas. This urban renovation has represented the physical support for a very clear strategy for reinventing the image of the city. As mentioned on the cases of Barcelona and Bilbao, commodified cosmopolitanism and marketed romanticism can be found on the selection of cultural material to compound this new international image. This is a branded image that is based on a specific idea of mediterraneity in which some local pre-existences, such as the traditional

\footnotetext{
${ }^{5}$ See the survey elaborated and published in 2004 by the New Economics Foundation Clone Town Britain. The Loss of Local Identity on the Nation's High Streets [25].
}

agricultural landscape -la Horta- or the vernacular architecture characterising the neighbourhoods near the seafront -el Cabanyal- have been clearly disregarded. On the contrary, the Mediterranean images selected on the urban renovation are closer to the landscape created in tourism resorts all over the world. This is a reinvention of the urban landscape which is supported by both the construction of specific architectural landmarks, such as the Santiago Calatrava's Arts and Sciences City, and the celebration of key big events, such as the $32^{\text {nd }}$ America's Cup or the recently announced plans to create a Formula 1 urban circuit similar to the one existing in Montecarlo.

Finally, cities in Spain have been intensively developing urban sprawl areas on the outskirts of traditional compact cities. Spanish cities have been conceived historically characterized by the archetypal image of density, urban complexity and social diversity. However, the increasing development of urban sprawl shows a very different urban scenario. Metropolitan spaces along the edges of the motorways and orbital ring roads have intensively developed low-density residential areas manifesting highly standardised morphological criteria in different cities. The construction of detached terrace-houses and semi-detached houses has been continuously growing over the last twenty years on the main seven Spanish metropolitan regions: Madrid, Barcelona, Valencia, Seville, Saragossa, Malaga and Bilbao. In the case of Barcelona, the volume of newly-built single-family houses was running at more than $70 \%$ during the period 1985-2005 in towns under 10.000 inhabitants and the available data for the global metropolitan region reveal an average construction rhythm of one condominium per hour over the last decade. In functional and morphological terms, the traditional Mediterranean model of the dense and compact city is subsumed into more diffuse urban sprawl.

This sprawlscape is made of a discontinuous sequence of physical elements: the semi-detached houses themselves, the roundabouts for the distribution of domestic traffic, the new petrol-stations, or the shopping malls. From a cultural perspective, these standardised landscapes are clearly based on the archetypical images of the American dreamscape of suburbia.

The disposition and materials used on specific elements such as porches, front doors, façades or chimneys and the design of the family spaces inside -such as the living or the back yard- compose a thematised domesticity that invites to think the previously quoted "domestication by cappuccino" as "domestication by barbecue".

Besides the evident environmental problems caused by urban sprawl, such as consumption of natural resources or the increasing mobility rates, cultural and social risks can also be detected. In this sense, the lack of urban complexity and diversity which characterises these residential areas is a problem that affects the realm of urban design and of the public space. The simplicity of the urban matrix and the standardised uses of urban space go hand in hand with the homogeneity that normally characterises social structure in these new neighbourhoods. They are inhabited by the same typology of urban population: households made up of couples and families with common trends in reference to their professional skills, consumption habits and urban behaviour. This lack of social diversity represents a very 
significant change regarding one of the main attributes that has historically characterised Spanish traditional compact cities.

In this new urban context, the repetition and predictability of space have also been reinforced by the increasing development of security policies associated with urban design. As previously mentioned, the hypervisibility of urban security conditions is one of the clearest requirements supporting urbanalisation. New low-density neighbourhoods in Spanish cities do not include walls separating them from the non-urban surroundings but they are designed offering general safety conditions and security devices and infrastructure. Bunkers and refuges complementing housing design represent the most extreme case, meanwhile security systems and surveillance devices are the more successful products provided by private security companies. $90 \%$ of the demands for the very basic standard residence alarm "kit" in Spain come from private households that are located in low-density neighbourhoods on the city outskirts. "Protected by...", "Connected 24 hours" are common highlights in the brochures of these new condominiums that are offered with "security box" and security alarm pre-installation. Unwelcoming adverts in doors and entrances, aggressive dogs in private gardens and fenced alarms in windows finally compose the domestic landscape created by private security. The increasing presence of this securityscape contributes to reinforce the equalisation dynamics previously mentioned.

It is true that differences in urban landscape and local culture can be found when comparing compact cities in Spain, but these differences evanish as soon as the main highways take you to the metropolitan spaces in-between them. In these interstices, the disconnection between place and landscape reveals itself as the main responsible for the appearance of the banalscapes.

\section{BANALSCAPES AS A GLOBAL URBAN FORM}

Coming back to the theoretical work of Guy Debord [8], the production of banalscapes can also be discussed considering the two definitions of the idea of spectacle previously quoted, that are suggested in The Society of the Spectacle. According to both definitions:

Firstly, banalscapes constitute themselves as a vehicle to create relationships between people mediated by images.

Secondly, banalscapes constitute a specific kind of landscape which, despite being offered to the city inhabitants, has been produced serving the interests, requirements and necessities of the global economy of leisure, entertainment and cultural tourism. This means that landscape configures itself as "capital accumulated to that level in which it has become image". This is the mechanism which makes the final results of urban renovation appear as similar despite being located in very different cities.

The global urban space does not only refer to the space of corporative business headquarters, with its high-tech architecture, and neither is it the archetypal financial landscape of the specialised downtowns. A very wide range of new urban spaces are nowadays part of this dominium: historical centres; old industrial areas experimenting with processes of renovation; urban waterfronts, or new urban sprawl areas on the city outskirts. All of them reveal themselves as a global urban space. In these territories, a kind of urban landscape 'locally globalised' begins to appear with authority and almost ubiquitous presence. This is a landscape which has simply been 'exchanged' into a banalscape.

\section{URBANISATION AS AN EQUALISER OF TIME AND SPACES}

Vincent: Do you know something funny about Europe?

Jules: What?

Vincent: The little differences. They have the same shit we have here but everything is a little different.... Do you know what they call the quarter pounder with cheese in Paris?

Jules: Don't they call it quarter pounder with cheese?

Vincent: No, they have the metric system and have no fucking idea of what a quarter of a pound is!

Jules: What do they call it?

Vincent: They call it ... Royale with cheese. Mac?

Jules: Royale with cheese... and what do they call a Big

Vincent: Well, a Big Mac is a Big Mac.... but they call it Le Big Mac.

Quentin Tarantino, Pulp Fiction, 1994.

Summarising what has been said, banalscapes represent a generic built environment where similarities in urban design and architecture go hand in hand with the equivalence of uses and behaviours hosted by urban space. However, it is difficult to suggest the existence of a global process of homogenisation between different cities and places. It is true that globalisation deals with the repetition of some key spaces which are similarly cloned in cities around the world. This clearly happens with the omnipresence of the global franchising economy represented by brands colonising commercial urban spaces in cities. However, at the same time, differences between cities still exist and remain.

Taking into consideration this last statement, the debate between those scholars defending the homogenising power of globalisation and those others posing the singularity of places as a source of resistance to that global trend, becomes too dependent on the analysis of specific study cases presented to support one or another explanation. In my opinion, what makes universal the process of urbanalisation is the management of the differences. This is to say, urban spaces and landscapes are not identical but they can appear as similar as the management of local peculiarities allows. This tension between the global and the local defines the evolution of urban landscape at the present moment. Maybe this can explain why the Kentucky Fried Chicken restaurants in Asian cities like Bangkok present Colonel Sanders -the company logo- with the same familiar appearance, given by his beard, glasses and smile, as any other Kentucky restaurant around the world, while the shape of his eyes respect the local physical features. This means, a little difference. 
Urbanalisation, though, does not mean the homogenisation among cities but just the opposite: the recognition and management of their differences. This is to say that the metaphors normally used to decode the effects of globalisation on urban space can be considered as clearly simple and the result of a reductionist approach. So, discourses such as the existence of a global architecture; the global domain of mass-media; or the imposition of homogeneous economic models and lifestyles all around the planet, simplify a process which is obviously global in its dimension but much more complex and dynamic in its nature.

More than suggesting an equalisation or homogenisation of places, it is worth thinking about in the development of some measurability and standardisation criteria. Pietro Barcellona [26] put some light on this discussion when analysing the global impact of mass-media on culture:

...The authentic step given on the formation of a new common language... it is constituted by mass-media and information and telecommunication technologies... they make possible both uniformity of language and the new domesticated differences... they are not merely a mirror for those differences... but a real transformer changing them into measurable entities...

In other words, the differences do not disappear and neither are they erased by the globalisation process. They actually continue existing but the global discourse make them appear as comparable and measurable. This is to say, globalisation standardises criteria normally used for their comprehension. In this sense, urbanalisation can be understood as a real transformer framing and making the differences between cities and places domestic. Differences are difficult to be read and understood because of their own singularity, but urbanalisation locates them into a much simpler and understandable visual order.

A metaphor can throw light on this complex process: the sound equaliser normally present on your stereo. Synthetically, the process of equalisation of a melody means reaching a right balance between low and high tones. This clears the imperfections on the sound to get a clear and transparent sound.

This process, digital or analogical, allows us to listen to musical pieces of the same gender, for example, different arias in operas, defining the precise level of equalisation required for making sopranos and baritones contribute to the hearing in the right measure. But the same equaliser also allows us to repeat the process in the case of a different musical gender: from the more aggressive industrial rock to the delicate oriental folklore, from new-age compositions to the very peculiar sound of flamenco guitars.

In other words, the equaliser gives place to a much more efficient management of the differences, diminishing some sounds and increasing others, making clearer some voices and darker others. All the compositions are different and they obviously maintain these differences but they have been equalised to compose a balanced musical narration.

My point is that urban design and architecture are, in fact, tools serving a very similar equalisation of urban time and spaces. This is where its global nature can be founded and not in the analysis of the similarities on the built environment per se. Urbanalisation changes the creases, the folds, the imperfections, in other words, the differences characterising urban places and landscapes into a flat surface. Equalisation makes those differences appear as easily digestible and comparable without any need to erase them. In this sense, urbanalisation constitutes itself as a process of urban simplification in which diversity and complexity contained within the city spaces are reduced to fit into a common visual order.

\section{REFERENCES}

[1] Muñoz F. Urbanalización: territorio y paisaje en la ciudad multiplicada. In Letria, J. (int.) A Cidade. Cascais: Cámara Municipal de Cascais 2001; pp. 173-208.

[2] Muñoz F. Lock living: urban sprawl in mediterranean cities. In Cities. Int J Urban Policy Plann 2003; 20(6): 381-85.

[3] Muñoz F. Paisajes banales: bienvenidos a la sociedad del espectáculo. In de Solà-Morales, I; Costa, X. Metrópolis: ciudades, redes, paisajes. Barcelona: Gustau Gili 2005; pp. 78-93.

[4] Muñoz F. Urbanalización: paisajes comunes, lugares globales. Barcelona: Gustau Gili 2008.

[5] Ventura M, Ed. Grandi eventi. La festivalizzazione della politica urbana. Venezia: Il Cardo 1994.

[6] Zukin S. Landscapes of power: from Detroit to Disney world. Los Angeles: University of California Press 1991.

[7] Zukin S. Urban lifestyles: diversity and standardisation in spaces of consumption. Urban Stud 1998; 35(5/6): 825-40.

[8] Debord G. La sociedad del espectáculo. Madrid: Castellote 1986.

[9] Pardo JL. La banalidad. Barcelona: Anagrama 1989.

[10] Harvey D. From space to place and back again: reflections on the condition of postmodernity. In Bird J, Curtis B, Putnam T, Robertson G, Tickner L, Eds. Mapping the futures. Local cultures, global change. London: Routledge 1993; pp. 3-28.

[11] Nel·lo O. Políticas urbanas y gobierno metropolitano en el proceso de integración europea. In: Ciudad y Territorio. Estudios Territoriales III 1995; 106: 783-92.

[12] Nel·lo O. "Spain". In: Van den Berg L, Braun E, Van der Meer JV. National urban policies in the European Union. Responses to urban issues in the fifteen member states. European Institute for Comparative Urban Research (EURICUR). Rotterdam: Ashgate 1998.

[13] Philo C, Kearns G. Culture, history, capital: a critical introduction to the selling of places. In: Philo C, Kearns G, Eds. Selling places. The city as a cultural capital, past and present. Oxford: Pergamon press 1993; pp. 1-32.

[14] Murzyn M. The central European experience of urban regeneration. Cracow: International Cultural Centre 2006.

[15] Hannigan J. Fantasy City: pleasure and profit in the postmodern metropolis. London: Routledge 1998.

[16] Zukin S. Loft living: culture and capital in urban change. London: Johns Hopkins University Press 1982.

[17] de Solà-Morales I. Diferencias: topografía de la arquitectura contemporanea. Barcelona: Gustau Gili 1995.

[18] Urry J. Consuming places. London: Routledge 1995.

[19] Urry J. The tourist gaze: leisure and travel in contemporary societies. London: SAGE 1996.

[20] Crilley D. Architecture as advertising: constructing the image of redevelopment. In: Philo C, Kearns G, Eds. Selling places. The city as a cultural capital, past and present. Oxford: Pergamon press 1993; pp. 231-52.

[21] Bohigas O, Martorell J, Mackay D. La Vila Olímpica, Barcelona 1992: arquitectura, parques, puerto deportivo. Barcelona: Gustau Gili 1991.

[22] Fundaró S. Omologazione e identità nella produzione degli spazi centrali. Metropolis. Postgraduate program in architecture and urban culture. Multicopied. Barcelona: Universitat Politècnica de Catalunya 1995.

[23] Barber S. Fragments of the European city. London: Reaction books 1995.

[24] Ingersoll R. Sprawlscape: il paesaggio come redenzione. In: Rossi A, Durbiano G, Governa F, Reiniero L, Robiglio M, Eds. Linee nel 
paesaggio: esplorazione nei pesaggi della dispersione. Torino: UTET 1999.

[25] Conesbee M, Kjell P, Oram J, Bridges PJ, Simms A, Taylor J. Clone Town Britain: the loss of local identity on the nation's high streets. London: The New Economic Foundation 2004.
[26] Barcellona P. Postmodernidad y comunidad. El regreso de la vinculación social. Madrid: Trotta 1992.

Received: April 7, 2009

Revised: May 10, 2009

Accepted: May 15, 2009

(C) Francesc M. Muñoz; Licensee Bentham Open.

This is an open access article licensed under the terms of the Creative Commons Attribution Non-Commercial License (http://creativecommons.org/licenses/by$\mathrm{nc} / 3.0 /$ ) which permits unrestricted, non-commercial use, distribution and reproduction in any medium, provided the work is properly cited. 